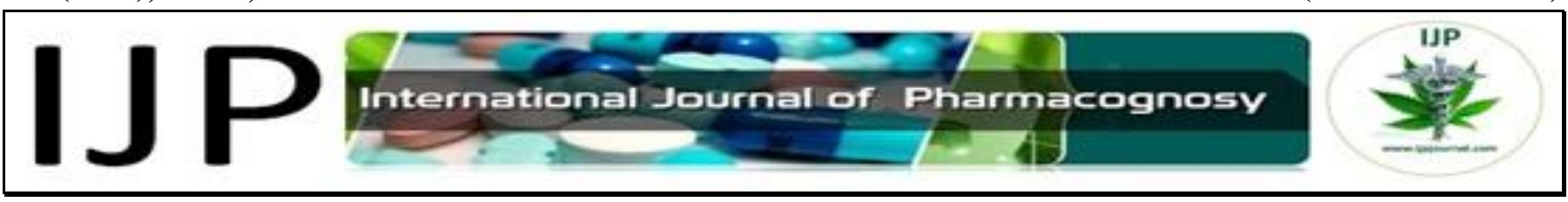

Received on 07 October 2015; received in revised form, 26 November 2015; accepted, 29 November 2015; published 30 December 2015

\title{
PHARMACOGNOSTIC AND PHYTOCHEMICAL EVALUATION OF CARYOTA URENS LEAF
}

\author{
Mariyan R. Patel $^{*}{ }^{1}$, Hiteksha S. Panchal ${ }^{2}$ and Ajay K. Saluja ${ }^{1}$
}

Indubhai Patel Pharmacy College \& Research Center ${ }^{1}$, Dharmaj - 388430, Gujarat, India. Anand Pharmacy College ${ }^{2}$, Anand - 388001, Gujarat, India.

Keywords:

Caryota urens, Macroscopy, Microscopy, Phytoconstituents, $\mathrm{R}_{\mathrm{f}}$ (Retention factors)

Correspondence to Author:

Mariyan R. Patel

Indubhai Patel Pharmacy

College \& Research Center,

Dharmaj - 388430, Gujarat, India.

E-mail: mary.patel20@gmail.com
ABSTRACT: Caryota urens (Palmae) is native to India. This tree species has been of interest to researchers because it is a medicinal plant employed in the indigenous Indian system of medicine. Pharmacognostic standardization, physicchemical evaluation of the leaves of Caryota urens was carried out to determine its macro-and microscopical characters and also some insoluble ash and sulfated ash values, alcohol- and water-soluble extractive values were determined for phytochemical evaluations. Preliminary phytochemical screening was also done to detect different phytoconstituents. Microscopically, leaf showed lamina, midrib regions, stomata. Powder microscopy showed mesophyll region, pitted xylem vessels and paracytic stomata. TLC of petroleum ether and ethanol extract showed three spots using hexane: ethyl acetate (12:4) and three spots using chloroform: ethyl acetate (5:4). Phytochemically leaves exhibited phytosterols, flavanoids, tannin carbohydrates, and phenolic compounds.

\section{INTRODUCTION: Caryota urens which is} popularly known as Shankarjata in Ayurveda is distributed more or less throughout Sub Himalaya tract from Nepal eastwards, Very common in Ghats and submontane forests of Mysore, in Malabar, Coorg, Konkan, Cochin, and Travancore. Also in tropical Asia, Malaya, Singapore, Australia, and Ceylon ${ }^{1,2}$. Leaf is reported to cure hemicranias ${ }^{3}$ and Root of the plant is reported for treatment of abortion, dysentery and tooth cavity to prevent decay ${ }^{4}$. Literature revealed that pharmacognostic studies had not been reported for the leaf of this plant. Therefore, the main aim of the present work is to study the macro, microscopic and some other pharmacognostic characters and physicochemical standards of the leaf of Caryota urens which could be used to explore this plant.

\begin{tabular}{|c|c|}
\hline \multirow[t]{2}{*}{ QUICK RESPONSE CODE } & $\begin{array}{c}\text { DOI: } \\
\text { 10.13040/IJPSR.0975-8232.IJP.2(12).582-86 }\end{array}$ \\
\hline & $\begin{array}{l}\text { Article can be accessed online on: } \\
\text { www.ijpjournal.com }\end{array}$ \\
\hline DOI link: http://dx.doi.o & 10.13040/IJPSR.0975-8232.IJP.2(12).582-86 \\
\hline
\end{tabular}

MATERIALS AND METHODS:

Collection of Plant Material: The plant Caryota urens was authenticated by Dr. Bhanu Kakrani, Lecturer, Department of Botany, Tolani College of Arts \& Science, Adipur (Kutch). Voucher herbarium specimen [HSP/TO-6/37] is preserved along with crude drug sample at the herbarium of A. R. College of Pharmacy, Vallabh Vidyanagar.

\section{Pharmacognostic Evaluation:}

Macroscopy: The macroscopic characters such as color, odor, taste, nature, texture were studied for morphological investigation. The shape, apex, base, margin, taste, and odor were determined in case of leaves 5 .

\section{Microscopy: ${ }^{6}$}

Preparation of Transverse Section of Leaf and Stem: The T.S. of leaf and stem were cleared of coloring matter by heating with chloral hydrate. After clearing, the set of slides were mounted in glycerin. Another set of sections was stained with phloroglucinol and concentrated hydrochloric acid (1:1) mixture for differentiating lignified tissues. The third set of sections was treated with dilute 
iodine solution. All the sections were then observed under $10 \mathrm{X}$ and $45 \mathrm{X}$.

Surface Preparation of the Leaf: A small portion of leaf ( $2 \mathrm{~mm}$ square) was placed in chloral hydrate solution in a test tube; epidermis was exposed by the scrapping of the tissues with a sharp edge of the razor on the glass slide. Water was added slowly and continuously scrapping was done till transparent. The portion was mounted in a mixture of an equal part of glycerin.

Powder Preparation of Leaves and Stem: The aerial parts of Caryota urens were dried under shade. The plant parts were powdered by grinding and passed through the sieve number 60. Finally, from this coarse powder, the microscopical examination was done. Slides were prepared in the same manner as mentioned in the above method.

Quantitative Microscopy: ${ }^{7}$ Quantitative leaf microscopy to determine palisade ratio, stomatal number, stomatal index, palisade ratio, vein islet number, and vein termination number were carried out on epidermal strips. Other quantitative microscopical parameters are a determination of fiber size in the powder of aerial parts.

Proximate Analysis: 8, 9, 10 The ash values, extractive values, moisture content, crude fiber content, swelling index, elemental analysis, foaming index were performed according to the official methods prescribed in Indian Pharmacopoeia and the WHO guidelines on quality control methods for medicinal plant material.

Phytochemical Analysis: The dried powdered plant material was successively extracted with the solvents of increasing polarity in a Soxhlet apparatus utilizing petroleum ether (60 - 80), toluene, acetone, chloroform, methanol, and water. The liquid extracts obtained with different solvents were collected, and the consistency, color, appearance of the dried extracts and their percentage yield were noted. The extracts obtained from powder by successive solvent extraction were subjected to qualitative examination for the phytoconstituents like alkaloids, glycosides, carbohydrates, phytosterols, fixed oils, saponins, phenolic compounds, tannins and flavonoids, proteins and amino acids by the reported methods $11,12,13$. Photomicrographs were obtained by observing free-hand sections of drug under compound Trinocular microscope (Labomed-Lx004).

Physicochemical Evaluations: Physicochemical parameters of Caryota urens leaf powder were determined and reported as total ash, water-soluble ash, acid-insoluble ash, and sulfated ash values. Alcohol and water-soluble extractive values were determined to find out the amount of water and alcohol soluble components ${ }^{14}$. The moisture content was also determined. As a part of quantitative microscopy stomatal number, stomatal index and fiber size were determined by using fresh leaves of the plant ${ }^{9}$.

\section{RESULTS AND DISCUSSION:}

Macroscopy: Leaf is $24-28 \mathrm{~cm} \times 6-8 \mathrm{~cm}$, triangular, dark to light green color, premorse apex, Irregularly serrate; equal sided at the base; smooth surface both side, venation parallel; Fig. 1 Taste: sweet; Odour: without characteristic.

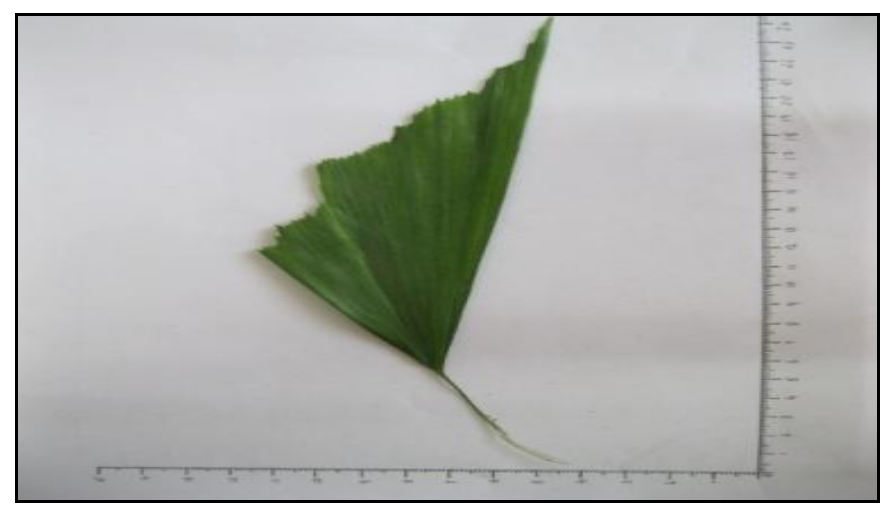

FIG. 1: EXTERNAL MORPHOLOGY OF C. URENS LEAF

\section{Microscopy:}

Transverse Section of Leaf: A Transverse Section of the leaf shows lamina and midrib portion. Leaf is the isobilateral type; it is not differentiated into palisade and spongy parenchyma. Upper and lower epidermis (Ep) having no trichomes. Upper and lower epidermis both are double layered. Midrib portion is well developed with lignified parenchyma in which some parenchymas are pitted. In the middle region, the presence of vascular bundles in distributed position and some tracheids are also there.

Surface Preparation of Leaf: In the surface view of the leaf, the lower epidermal cells having more no of stomata than in upper epidermis. It shows paracytic type stomata. 
Powder Microscopy of Dried Powder of Leaf: The powder of $C$. urens was a greenish color, without characteristic odor and with a sweet taste. When powder was mounted with chloral hydrate,

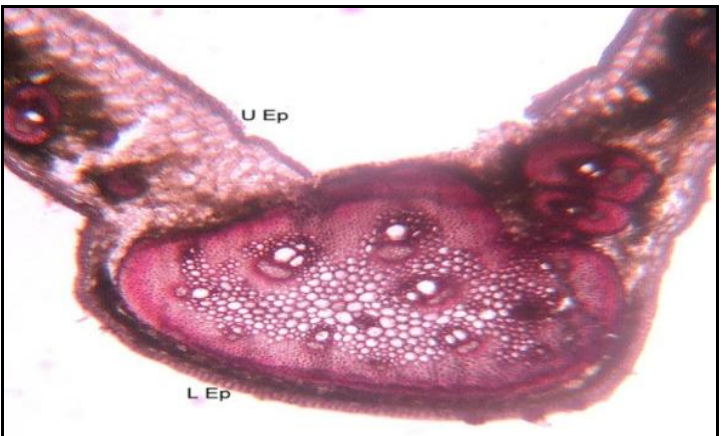

(A) Section of the leaf phloroglucinol and $\mathrm{HCl}$ the following elements were observed: Mesophyll region which contains palisade with epidermis paracytic stomata Fig. 4.

FIG. 2: MICROSCOPICAL VIEW OF C. URENS LEAF

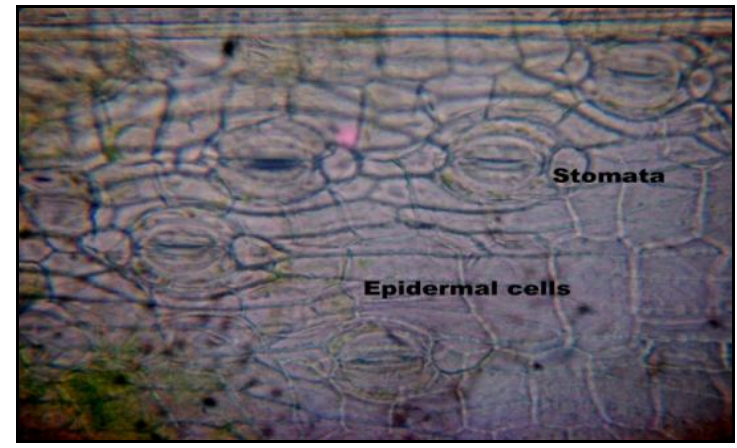

(A) Lower epidermis

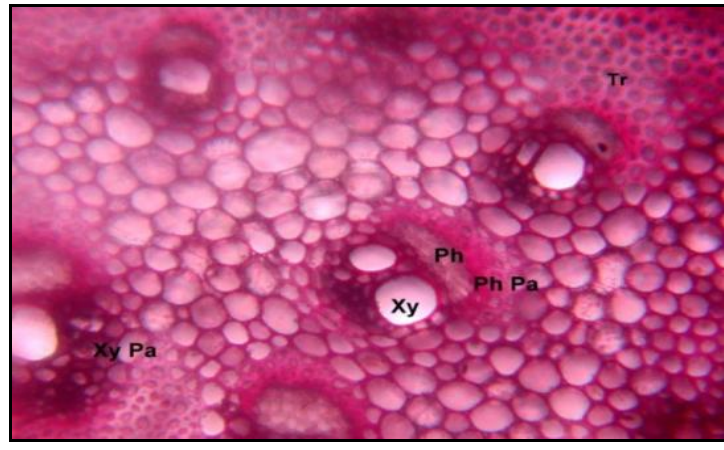

(B) Vascular bundle

FIG 3: SURFACE PREPARATION OF C. URENS LEAF

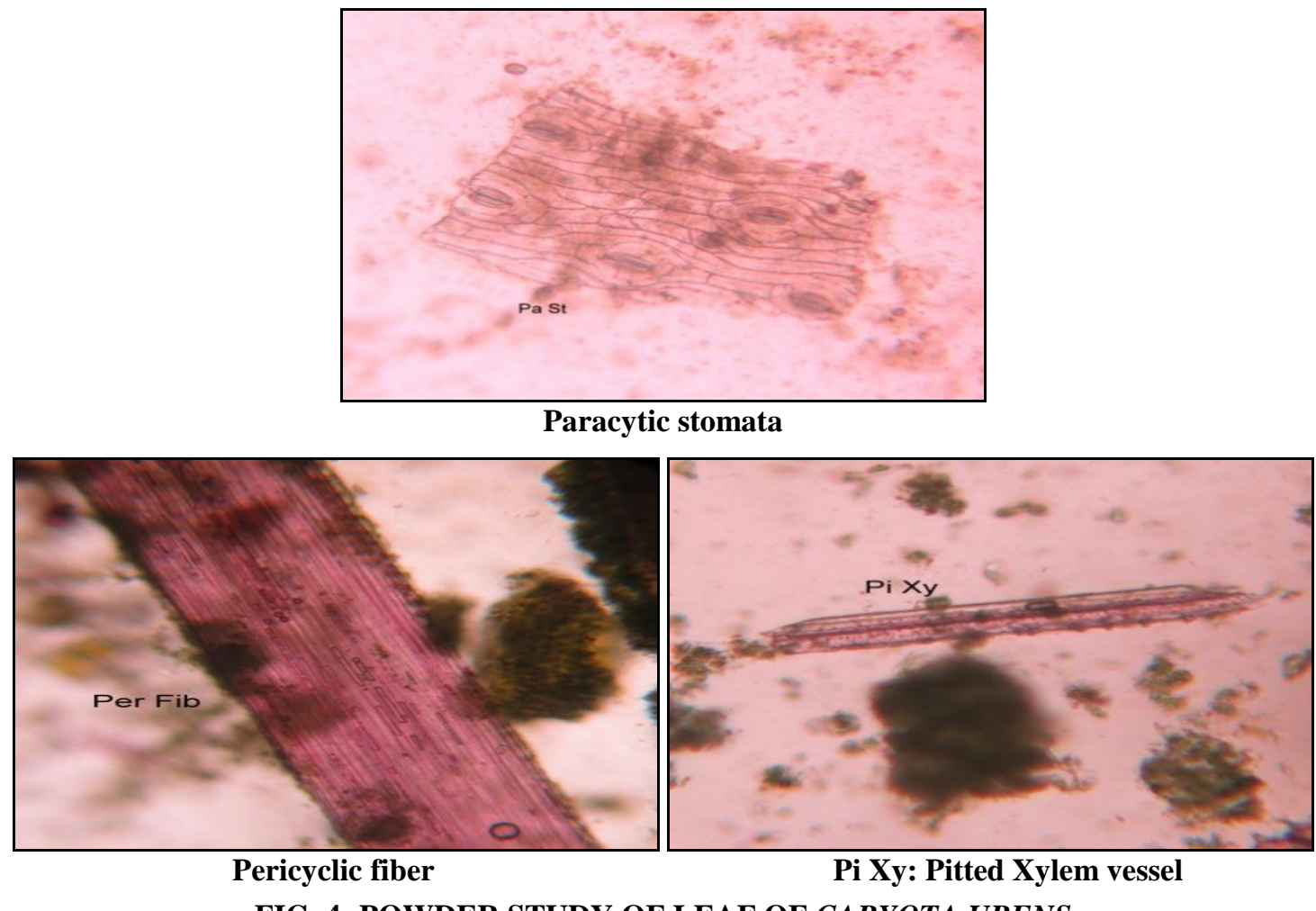

Paracytic stomata

Pericyclic fiber

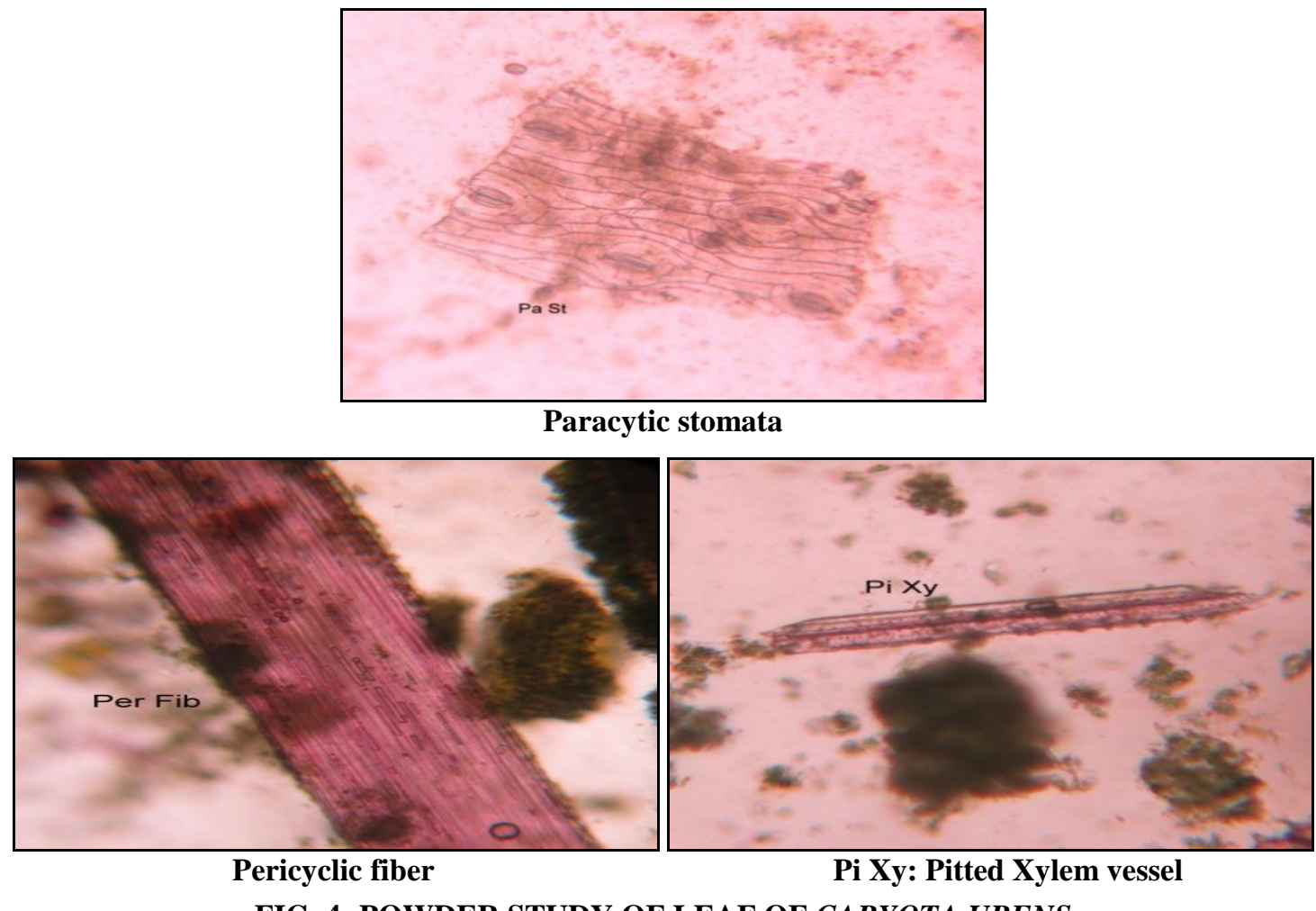

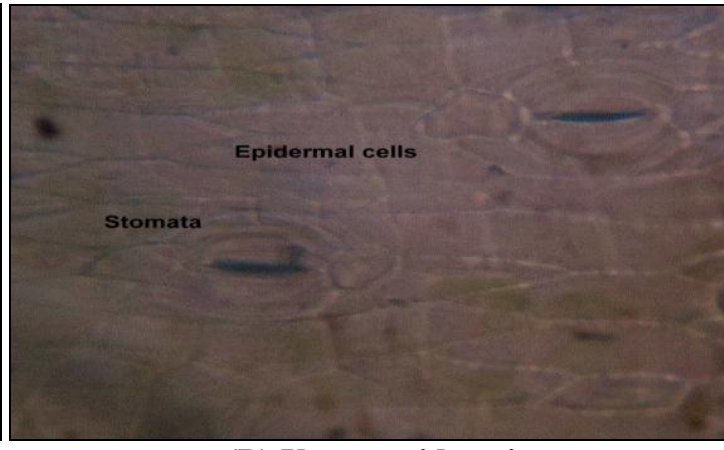

(B) Upper epidermis

FIG. 4: POWDER STUDY OF LEAF OF CARYOTA URENS 


\section{Physicochemical Evaluation: ${ }^{11}$}

TABLE 1: PHYSICOCHEMICAL EVALUATIONS OF LEAF OF CARYOTA URENS

\begin{tabular}{ccc}
\hline S. no. & Parameter & Result \\
\hline 1 & Stomatal number & Lower epidermis: 275 \\
2 & Stomatal index & Upper epidermis : 50 \\
& & Lower epidermis: 14.66 \\
3 & Fibre size & Upper epidermis :4 \\
& & Length : $145.19 \mu \mathrm{m}-359.54 \mu \mathrm{m}$ \\
4 & Total ash & Width $: 3 \mu \mathrm{m}-7 \mu \mathrm{m}$ \\
5 & Water-soluble ash & $19.37 \% \mathrm{w} / \mathrm{w}$ \\
6 & Acid-insoluble ash & $4.75 \% \mathrm{w} / \mathrm{w}$ \\
7 & Water-soluble extractive value & $15 \% \mathrm{w} / \mathrm{w}$ \\
8 & Alcohol-soluble extractive value & $17.04 \% \mathrm{w} / \mathrm{w}$ \\
9 & Moisture content & $15.94 \% \mathrm{w} / \mathrm{w}$ \\
\hline
\end{tabular}

w/w- weight/weight

Phytochemical Analysis:

Preliminary Profiles of Successive Solvent Extracts: ${ }^{15}$ C. urens leaves showed the presence of moisture content- $3.29 \% \mathrm{w} / \mathrm{w}$; total ash, insoluble acid ash and water-soluble ash determined were $19.37,15$ and $4.75 \%$ w/w, respectively. The water-soluble extractive value was 17.04; alcohol-soluble extractive value was
15.94; the color consistency and \% yield of successive extractive values of powder were petroleum ether $\left(60-80{ }^{\circ} \mathrm{C}\right.$ ) (yellowish brown, sticky mass, 4.7), toluene (Brownish black, sticky mass, 2.53), chloroform (Brownish black, sticky mass, 1.49), ethanol (Brownish black, sticky mass, 13.23), water (Dark brown, solid mass, 4.82) Table 2.

TABLE 2: PRELIMINARY PROFILE OF SUCCESSIVE SOLVENT EXTRACTS OF LEAVES OF CARYOTA URENS

\begin{tabular}{cccc}
\hline S. & Solvent & $\begin{array}{c}\text { Colour and consistency } \\
\text { after drying }\end{array}$ & $\begin{array}{c}\text { Average } \\
\text { value (\%w/w) }\end{array}$ \\
\hline 1 & Petroleum ether $\left(60-80{ }^{\circ} \mathrm{C}\right)$ & Greenish sticky mass & $9.044 \%$ \\
2 & Toluene & Greenish solid mass & $4.125 \%$ \\
3 & Chloroform & Greenish solid mass & $2.91 \%$ \\
4 & Methanol & The yellowish green sticky mass & $11.5 \%$ \\
5 & Water & The reddish-brown, solid mass & $9.775 \%$ \\
\hline
\end{tabular}

Preliminary Phytochemical Screening: All the above extracts were tested with various reagents, and the results for the same are reported in Table 3 . The various extracts showed the presence of phytosterols, carbohydrates, phenolic compounds, flavonoids, tannins, proteins, amino acids, and mucilage.

TABLE 3: PHYTOCHEMICAL SCREENING

\begin{tabular}{cccccccc}
\hline $\begin{array}{c}\text { S. } \\
\text { no. }\end{array}$ & Constituents & $\begin{array}{c}\text { Pet. } \\
\text { Ether }\end{array}$ & Toluene & Chloroform & Acetone & Methanol & Water \\
\hline 1 & Phytosterol & + & + & + & - & - & - \\
2 & Saponins & - & - & - & - & - & - \\
3 & Proteins and amino acids & - & - & - & + & - & - \\
4 & Tannins and phenolics & - & - & - & + & + & + \\
5 & Carbohydrates & - & - & - & - & + & + \\
6 & Mucilage & - & - & - & - & - & + \\
7 & Flavonoids & - & - & - & + & + & + \\
8 & Glycosides & - & - & - & - & - & - \\
9 & Alkaloids & - & - & - & - & - & - \\
\hline
\end{tabular}


CONCLUSION: As there is no pharmacognostical anatomical work on records for this traditionally much-valued shrub, present work is taken up in the view to lay down the macroscopic and microscopic standards, which could be used in deciding the genuineness of the herb, irrespective of their collection from different sources. The colored photographs of the leaf of the plant mentioned above might facilitate the researcher for identification.

The results of the phytochemical screening, histochemical tests can be considered as distinguishing parameters to identify and decide the authenticity of $C$. urens and thus can be used as standards for reference purpose also. The outcome of the quantitative parameters described in the plant mentioned above parts (Leaf) might be useful in determining the authenticity of the drugs. HPTLC profile helps in standardization and also for undertaking work on isolating and identifying the bioactive compounds.

ACKNOWLEDGEMENT: The authors are thankful to the Principal, A. R. College of Pharmacy for evincing interest in this work. They are also grateful to Dr. Bhanu Kakrani, Lecturer, Dept. of Botany, Tolani College of Arts \& Science, Adipur (Kutch) for help in providing authentic plant material.

\section{CONFLICT OF INTEREST: Nil}

\section{REFERENCES:}

1. Shah GL: Flora of Gujarat state, Sardar Patel University Press, Vallabh Vidyanagar, Edition 1 ${ }^{\text {st }}$, Part 2, 1978: 693.

2. Chopra RN, Nayar SL and Chopra IC: A glossary of Indian medicinal plants, National Institute of Scientific Communication, New Delhi, Edition 1 ${ }^{\text {st }}, 1996: 53$.

3. http://www.ethnoleaflets.com/leaflets/madugula.htm

4. http://enchantingkerala.org/ayurveda/ayurvedic-medicinalplants/choondappana.php

5. Mathur J, Khatri P, Samanta KC, Sharma A and Mandal S: Pharmacognostic and preliminary phytochemical investigations of Amaranthus spinosus (Linn.) Leaves. Int J Pharm Pharm Sci 2010; 2(4): 121- 124

6. Nadkarni KM: Indian Materia Medica, Popular Prakashan, Mumbai, Edition 3d, Vol. I, 1976: 1227.

7. Anonymous: The Wealth of India, Raw materials, Publication and Information Directorate, CSIR, New Delhi, Vol. I, 1962: 277.

8. Anonymous: Quality Control Methods for Medicinal Plant Materials, Geneva: WHO, 1998.

9. Anonymous: The Ayurvedic Pharmacopoeia of India, partI, Ministry of Health and Family Welfare, Department of Health, Government of India, Vol. I, 1986.

10. Anonymous: Quality Control Methods for Medicinal Plant Materials, Geneva: WHO, 1998.

11. Khandelwal KR: Practical Pharmacognosy, Techniques and experiments, Nirali Prakashan, Edition $12^{\text {th }}, 2004: 9$, 149.

12. Kokate CK: Practical Pharmacognosy, Vallabh Prakashan, Delhi, Edition $4^{\text {th }}, 2005: 7,14,107$.

13. Anonymous: Indian Pharmacopoeia, Ministry of Health and Family Welfare, Govt. of India, Controller of Publication, New Delhi, Vol. 2, 1996: A-47, A-53, A-54.

14. Anonymous: The Ayurvedic Pharmacopoeia of India, Ministry of Health and Family Welfare, Department of health, Govt. of India, Edition 1 ${ }^{\text {st }}$, Vol. I, 1986: 143.

15. Mukharji PK: Quality Control of Herbal Drugs, Business Horizons Pharmaceutical Publishers, New Delhi, Edition $1^{\text {st }}, 2002$ : 186-195.

16. Harborne JB: Phytochemical Methods. London: Chapman and Hall, 1998.

How to cite this article:

Patel MR, Panchal HS and Saluja AK: Pharmacognostic and phytochemical evaluation of Caryota urens leaf. Int J Pharmacognosy 2015; 2(12): 582-86. doi link: http://dx.doi.org/10.13040/IJPSR.0975-8232.IJP.2(12).582-86.

This Journal licensed under a Creative Commons Attribution-Non-commercial-Share Alike 3.0 Unported License.

This article can be downloaded to ANDROID OS based mobile. Scan QR Code using Code/Bar Scanner from your mobile. (Scanners are available on Google Playstore) 